\title{
The Formation Process of Terms from Common Albanian Words in Technical Terminologies (Mechanical, Electrical, Construction)
}

\author{
Dr. Dipl. Ing. Gani Pllana \\ University of Prishtina "Hasan Prishtina" Faculty of Mechanical Engineering Republic of Kosova \\ Prof. ass. Dr. Sadete Pllana \\ University of Prishtina "Hasan Prishtina" Faculty of Economy Republic of Kosova
}

\begin{abstract}
In this paper, in a more pronounced way we are exploring with priority the formation process of terms from Albanian common words in technical terminologies (mechanical, electrical, construction). The influence of the scientific-technical language on the general one will be further strengthened in future, because science and its language are beginning to play an increasingly more important role on the development of culture in general. Under the influence of these factors, the terminology lexicon and the general lexicon are getting every step closer, where, an intellectualized lexicon is serving as the basic interlink which exists in both macro-layers. On the other hand, this problem could be linked in a particular way with the formation in the course of the times, of the technical terminology built on the basis of words of the native language, which are raised to the level of terms for the nomination of specialized concepts of this field. Thus, for example, a range of words can be brought forward, which we come across as early as in Buzuk's creation "Meshari" ("Missal") (1555), which today are used as terms also, not only directly in today's technical fields, like: fuqi, forcë, bosht, rrotë, rrotullohet (rrotulluem), (Engl. power, strength, axle, wheel, spinning (spinned) etc. As is evident, on this basis primarily Albanian terminology formations are created, alongside formations originating from foreign languages, as well as those built on the basis of authentic Albanian and of word formative models and types (term formative) thereof: boshtor, i rrotullueshëm (Engl. axial, rotating) etc.
\end{abstract}

Keywords: terms, formation process, common Albanian words, terminology, mechnical, electrical, constraction.

\section{Introduction}

To date Albanian terminology was studied in the form of special terminologies, starting from terminologies of more or less broader fields, like: economy, medicine, mechanics, agriculture and any other within them, such as agronomy, or even narrower. From terminologies of wider areas fundamental generalizations were achieved, but also from the narrower ones it was possible to undertake a thorough study of their specific issues. Partial generalizations discovered more detailed aspects of problems, especially specific aspects of synonyms, antonyms for specific areas, like for example, problems of polysemy for a limited field, when it appears as hybrid like the terminology of agricultural tools, the terminology of the field of mechanism theory etc.

In the conditions of the rapid development of technics and technology in recent years, the cooperation of the scientifictechnical language with the standard Albanian language is continuing with a higher intensity than before. We notice a vigor of enrichment in the vocabulary of technical terminology, due to the birth and formation of new fields and subfields of technics, technology, as computing, mechatronics, telemetry, a multitude of concepts many of which, on the one hand, are marked with names of the languages they come from, mainly from English, but on the other hand, they meet their needs with the lexical mother tongue composition (by common words being raised to terms) and with the activation of other layers, such as compound word terms.

As an object of special interest of this paper is precisely the view of ordinary words, since the time of their recording, not only in written texts, like for example in "Meshari" of Buzuk (1555), etc., also reflected in dictionaries of Albanian language 
like from the vocabulary of Frang Bardhi ${ }^{1}$ where we meet a series of words, which have functioned as special units and later became terms. Likewise, other later vocabularies become an research objects, like vocabularies of the general language, and as well the terminology type ones.

\section{Technical terminologies}

Technical terminologies originate from words related with concepts deriving from very old times and from different countries of the world, as universal linguistic, that have passed from one language to another at different times, translated, adapted, as borrowed words or words in their own right (indigenous). They were used as special words in various fields of human activity, later as terms in technical terminology and terminologies of other fields of knowledge, as has happened in the Albanian lexicon as well.

\section{Motivation of the terms}

Most of the terms are motivational in their conceptual content, which means that each term has a base from which it originates and just in the way the base is developed, so it developed as well it is content. However, one part of terms derive from common words and enter a knowledge field according to the quality of the term, while maintaining the conceptual content, ie. its content as a word or as a term is more or less the same. Here we are dealing with same concepts that pass from a low conceptual level (as a word) to a higher conceptual level (as a term). Thus, for example, can be considered a number of terms in the field of construction as derë (door), prag (sill), kat (level), dritare (window (const.)), gërmim (excavation), shirje (threshing), korrje (harvesting (agric.)). It should be noted here that each of them develop further as dritare (ndërtese), and dritare (fryrjeje), derë (ndërtese) dhe derë (furre); Engl: window (building), and window (aircontrol) door (building) and door (oven).

\section{The identity of the terms}

In the Dictionaries of terminology, as well as in those technics terminological ones, the identity of the terms is defined by the fields of knowledge in question, which the relevant terms represent, as, for example, term-words with a defined identity in the field, like derë, dritare, prag, tavan, çati, mur, Ilaç, suvatim (conct.), bosht, rrotë (mech.), llambë, fill, tel, kyç, shkyç (el.), (Eng. door, window, sill, ceiling, roof, wall, stucco, plastering (const.), shaft, wheel (mech.), lamp, yarn, wire, key, disconnect (el.), though even here many term-words are included in dictionaries of other fields (borrowed, terminologised etc.) as lopatë (Eng. blade) (mech., const.), krah (Eng. wing) (mech., const.) or with undefined boundaries as rrymë (Eng. current) (el.) /rrymë (Eng. current (mech.). Here the problem of the identity of terms, like the terms of specialized units and as belonging to a specific area, is about solved in compound word terms, where, they themselves identify the conceptual content (the concept) and the field, like rrymë e vazhduar (Eng.spread current) (el.), rrymë ajri (Engl. air flow) (mek.), mur tulle (Eng. wall brick) (const.) - mur cilindri (Eng. wall cylinder) (mech.), gur themeli (Eng. foundation stone) (const.) - gur mprehës (Eng. whetstone (mech.).

\section{The technical lexicon, as part of a scientific-technical style}

It is important to note that the technical lexicon, as part of a scientific-technical style; as formation at its origin and later consolidated, relates with the formation of technical fields of knowledge and belongs therefore to the period after the years 1912-1920, but, observed on the level of linguistic styles, it does relate, with religious styles and as with other styles, as is the political-social style (conditioned by social and cultural development of the place like the creation of societies, their culture and politics, their press) from which in the lexicon of technics general terms were borrowed, abstract words for the creation of compound word terms, as: kusht: kusht politik, kusht shoqëror and later kusht teknik, kusht kufitar (Eng. condition: political condition, social condition, and later technical condition, boundary condition). In the same way they entered the technical terminology: nga gjendje paqeje etj., gjendje e ngurtë, gjendje e gaztë. (Eng. from the state of peace, solid state, gaseous state etc.).

Later, with the formation of the scientific and the scientific-technical style in Albania, the technical lexicon entered as a separate system itself (which coincides with the Renaissance, during which the terminologies of mathematics, geometry, chemistry for low level education and later secondary education were incepted). Many terms from these fields contain the

\footnotetext{
${ }^{1}$ Bardhi, F.: "DICTIONARIUM LATINO EPIROTICUM", Romae, 1635.
} 
terminology of the scientific and theoretic foundation of the language of technics, like: kënd, rreth, barazim, pikë etj., as kënd i prerjes, pikë e rakordimit (Eng. angle, circle, equation, point etc., as in cutting angle, point of reconciliation), etc1.

Through units evidenced in different denominations unit links can be observed to each other and their process from one unit to another as a fjalë $\rightarrow$ profesionalizëm (Eng. word $\rightarrow$ professionalism) $\rightarrow$ a contemporary term. Thus, for example, the word shtëpi (Eng. home) we find since Buzuku and it continues with other authors, but it so far has not created the status of a term in construction and in any other field, whereas in its place in the terminology of the construction it specialized as the term ndërtesë (building), which, from its own accord has been used as a word for the first time by Kristoforidhi. It needs to be emphasized that ndërtesë (building) is related to ndërtim (construction), while both relate to the verb ndërtoj (to build). The latter, as a verb we have come across it for the first time in Matrënga, dërtuarë (today me ndërtue, ndërtoj/Eng. to build, build). Ndërtoj (build) relates with the thematic-conceptual field to ngreh (raise) - ngreh (ngreh ndërtesën - ndërtoj ndërtesën, (Eng. raise a building - build a building); thus shtëpi (house) (Bz.) (nonterm); ndërtesë (building) (contemporary term); ndërtoj (build) (Ma.) (term); ngreh (raise) (Ma.), (contemporary term).

Similarly plug (plow) (as a term) is met for the first time in the Dictionary of 1954, when the technical terminology had not yet emerged. Plug (plow) connects conceptually with parmendë (plough) (which has remained in use like professionalism and its relationship with plug is confirmed in several languages: ital. aratro (for parmendë and plug) as in Eng. plough (also for parmendë and plug) as in Russian like in Albanian: parmendë-lemeh, whereas plug-pllug. In the further development as a concept (object) plug marks the plough (plug) as it was then, and also as it is today, plug as a machine (= overall plows). For this reason we support the proposal that in the second meaning, according to the model mbjellëse (harvesting) for plug as a machine (overall plows) to introduce pluguese (ploughing), which differentiates the tool from the machine, as (Mech. Dictionary of, 2002) $)^{2}$ sharrë-sharruese, rul-ruluese (Eng. saw-sawing etc) etc. Further we can see plug (plow) relating with paraplug (relating part of plow), where the latter can become paraplugues (tools).

In the same way, dritare (window) today is used as a term in construction and as terminologised in some other fields: dritare (air-control window) (met.) - dritare (disc) (inf.). It was created for the first time by N. Frashëri (circa 1900) and as such could not be reflected by previous authors. In its place before, the Turkish-borrowed word penxhere (window) could not be used, and as such appears for the first time in the Dictionary of 1954. With other authors, starting from Buzuku, we meet fënestrë (Bz., Bu., Bg.) as a foreign word, Italian, and only for the first time it appears as dritare in the Dictionary of 1954 (from N. Frashëri dritore).

\section{The groups of terms formed on the basis of meanings of common words}

The groups of terms formed on the basis of meanings of common words, derived from different sources that relate with different parts of ordinary life deal with objects, phenomena, processes that associate with them. So are used as terms in general technics and technology general words that mark:

\section{1) Terms built on meanings of words marking body parts of the human body:}

trup $_{1}$ (body 1 screw) (mech.), trup 2 (body 2 of ship) (naut.),

ballë 1 (gallery front 1 ) (min.), ballë2 (piston front 2 )(mech.),

hundë1 (hammer nose1) (mech.), hundë2 (nose 2 (nozzle)) (mech.) etc.;

2) Terms built on meanings of words that mark human clothing and their parts:

veshje $_{1}$ (fire resistant clothing 1 ) (mech.), veshje (lining $_{2}$ of canal) (const.),

kapotë (motor cover) (mech.), xhep (dust pocket) (mech.) etc.;

(3) terms built on meanings of words parking parts of trees:

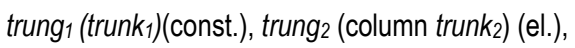

\footnotetext{
1 Duro, A.: "Fjala shqipe në terminologjinë e mekanikës", në "STUDIME FILOLOGJIKE”, nr.4, Tiranë, 1984.

${ }_{2}^{2}$ Fjalor i termave themelorë të mekanikës (shqip-anglisht-frëngjisht-italisht-rusisht), Tiranë, 2002.
} 
rrënjë1 (tree root1) (agr.), rrënjë2 (root2 of tooth (gear)) (mech.) etc.;

(4) terms built on meanings of words that mark animals, birds and body parts of animals or birds:

bri1 (anvil horn 1 ) (mech.), bri2 (steam ship horn 2 ) (naut.),

bisht $_{1}$ (tail 1 of lathe carrier) (mech.), bisht2 (handle of pitchfork) (agr.) etc.;

(5) terms built on meaninghs of words parking parts and accessories (tools) that humans use for personal hygiene:

furçë 1 (discal brush 1 ) (mech.), furçë2 (collector brush 2 ) (mech., const.),

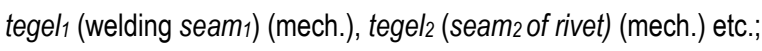

(6) terms built on meanings of words marking objects and working tools:

urë1 (automobile bridge ${ }_{1}$ ) (mech.), urë (railway bridge 2 ) (const.), urë, (electric bridge 3 ) (el.),

kovë1 (rubbish bucket 1 ) (met.), kovë2 (excavation bucket2) (mech.) etc.;

(7) terms built on meanings of words marking kitchen tools and equipment:

pirun 1 (fork1 cardan) (mech.), pirun2 (fork2 clutch) (mech.), pirun 3 (fork3 guide) (mech., const.)

lugë1 (mortar spoon 1 ) (const.), lugë2 (excavation spoon2) (mech.) ect.;

(8) terms built on meanings of words marking buildings and their internal and external components:

kullë1 (cooling tower 1 ) (mech.), kullë2 (drying tower 2 ) (mech.,const.,agr.),

dhomë1 (condensation room1) (mech.), dhomë2 (ventilation room 2 ) (mech.), dhomë̈ (vacuuming room 3 ) (mech.) etc.

Systemic developments of the technical terminology are discovered since the appearance in inception of the lexicon, evidenced since 'Meshari' and to this day, like in "Meshari" "Missal": forcë - forcojm (forcuom) - forcuos (Eng. force) and that continues with Matrënga, Budi, Bardhi, Bogdani, Kristoforidhi. Systemic-associative links appear more significantly in terminological vocabularies like in Bindoni, and in vocabularies of the terminological series. These links appear also in the form of microsystems, as in: punë - punoj - punim-i - punueshëm - përpunoj - përpunim - $i$ përpunueshëm përpunueshmëri; kokërr - kokrrizë - kokrrizoj - kokrrizim - i kokrrizueshëm - kokrrizueshmëri - kokrrizëti etc., (Eng. work - work - work-of - workable - process - processing - pliable - machinability; grain - grain - granule etc.).

\section{Conclusion}

From what we outlined above it can be concluded that from the point of view, that on the level of conceptual content each lexical unit of language is identified as a common word when it falls (is) in the low level, which is presented as the base of the word and as a specialized unit (word or compound word), when it operates in a high level, which is accepted also as the base term. This means that the identity of each unit; term or non-term (ie.), special unit or non-special unit, depends on the level it is used, where the conceptual content is primary and not the form, when the unit is single word (as described in the examples above, këmbë (njeriu) (fjalë) (Eng. foot (human) (word) and këmbë (minerali) (term) (Eng. foot (mineral) (term)) or derë ${ }_{1}$ (fjalë e zakonshme) (Eng. door 1 (common word) and derë, (term në ndërtim) (Eng. door2 (term in construction) and when the unit is a compound word (two words and more), where the conceptual content is revealed by the terms of the unit: këmbë e urës, derë rrotulluese (Eng. foot of bridge, revolving door).

We conclude that the lexicon of language can be divided into two main groups: the common lexicon (always identified as such despite the low level of conceptual contents of units, like foot, door, machine (used in common speech), machine (of State that oppresses democracy) and special lexicon: foot, door, machine and revolving door.

It should be emphasized however that the basis of their base is comprised by Albanian lexical units originating from remote times, which have served as word- and phrase forming themes for special units of crafts, handicrafts, as in rrotë $\rightarrow$ rrotulluom (rrotulloj) (Eng. turning wheel (turning)) (Buzuku), furkë e tjerrit, rrotë e qerrit (Eng. wheel of yarn, wheel of cart) (Buzuku) and until today as term forming topics (single words and compound words): rrotullues-e - $i$ rrotullueshëm, furrë $e$ rrotullueshme, derë e rrotullueshme (Eng. rotary-of - the rotary, rotary kiln, rotary door) etc. 


\section{Bibliography}

[1] Ashta, K.: "Leksiku historik i gjuhë shqipe I" (Gjon Buzuku), Universitetit i Shkodrës, "Luigj Gurakuqi", Shkodër, 1996.

[2] Bardhi, F.: "DICTIONARIUM LATINO EPIROTICUM", Romae, 1635.

[3] Bindoni, M.: VOCABOLARIO FJALUER, Tecnico-Agricolo, Teknik Bujqësuer (Italiano-Albanese, Italisht- Shqip; Albanese- Italiano, Shqip- Italisht), 4000 fjalë, Shtëpia Botonjëse Casa Editrice "Kristo Luarasi", Tiranë, 1935.

[4] Çabej, E.: "Pjetër Budi dhe gjuha e tij" në "Probleme të historisë së gjuhë shqipe", Prishtinë, 1971

[5] Duro, A.: "Fjala shqipe në terminologjinë e mekanikës", në "STUDIME FILOLOGJIKE", nr.4, Tiranë, 1984.

[6] Duro, A.: "Minimizing the negative effects of homonymy in language for special purposes",

[7] University of Vienna, 1995.

[8] Fjalor i terminologjisë tekniko-shkencore 8. Terminologjia e mekanikës (shqip-serbokroatisht-rusisht- frëngjisht), Prishtinë, 1970.

[9] Fjalor i termave themelorë të mekanikës (shqip-anglisht-frëngjisht-italisht-rusisht) , Tiranë, 2002.

[10] Leka, F. "Udhëzues për përpunimin e terminologjisë tekniko-shkencore", Tiranë, 1983.

[11] Memisha, V.: "Fjalor i termave themelorë të mekanikës" në "GJUHA JONË” nr.3-4, Tiranë, 2002.

[12] Pllana, G.: "Standardizimi i terminologjisë së inxhinierisë mekanike në gjuhën shqipe nevojë e kohës", në ALBANOLOGJIA International Journal of Albanology, Vol.1, USHT Tetovë, 2014.

[13] Pllana, G.: "Observations on antonyms in the field of thermodynamics" në 20154 rd International Conference on Language, Medias and Culture ICLMC 2015, April 09-10, 2015, Kyoto, Japan, 2015.

[14] Pllana, G.: Pllana, S.: "Gjendja dhe probleme të zhvillimit të terminologjisë se mekanikës teorike" Seminar i VItë i Albanologjisë, 20-23 shtator 2012, Tetovë-Shkup 2012.

[15] Sager, J.: "A practical course in terminology processing", Amsterdam, 1990.

[16] Xhuvani, A.: "Për pastërtinë e gjuhës shqipe", Prishtinë, 1968. 